\title{
The potential of Lepidium sativum L. for phytoextraction of Hg-contaminated soil assisted by thiosulphate
}

\author{
Beata Smolinska • Sylwia Rowe
}

Received: 8 March 2014 / Accepted: 28 September 2014 /Published online: 12 October 2014

(C) The Author(s) 2014. This article is published with open access at Springerlink.com

\begin{abstract}
Purpose The possibility of using higher plants to extract mercury from contaminated sites is dependent on both the concentration of $\mathrm{Hg}$ and its bioavailability. To increase the solubility of $\mathrm{Hg}$ in soil, some chemical compounds can be used. The aim of this study was to evaluate the effectiveness of $\mathrm{Hg}$ soil cleaning with the use of Lepidium sativum $\mathrm{L}$. and sodium thiosulphate, as well as the leach ability of $\mathrm{Hg}$ from soil after phytoextraction.

Materials and methods The experiment was conducted on soil artificially polluted by $\mathrm{Hg}$, wherein sodium thiosulphate was tested as a phytoextraction promoter. The $L$. sativum L. plants were used for phytoextraction. The leaching of $\mathrm{Hg}$ was assessed by determination of $\mathrm{Hg}$ concentration in water extracts. All determinations of $\mathrm{Hg}$ in soil, plant and water extracts were analysed by CV-AAS method after acid mineralization.

Results and discussion The result of the study showed that L. sativum $\mathrm{L}$. accumulated $\mathrm{Hg}$ from contaminated soil mostly in belowground tissues. Even less than $8 \%$ of $\mathrm{Hg}$ was translocated to the shoots of L. sativum L. Application of thiosulphate increased the total $\mathrm{Hg}$ accumulation over 238$272 \%$, depending on both the $\mathrm{Hg}$ and thiosulphate concentrations in soil. After thiosulphate treatment, translocation of $\mathrm{Hg}$ to shoots of $L$. sativum L. increased even 10 times relative to unassisted process. Thiosulphate did not negatively affect
\end{abstract}

Responsible editor: Peter Schroeder

B. Smolinska $(\bowtie)$

Department of Biotechnology and Food Sciences, Institute of

General Food Chemistry, Lodz University of Technology,

4/10 Stefanowskiego Street, 90-924 Lodz, Poland

e-mail: beata.smolinska@p.lodz.pl

S. Rowe

25 Mill Park, Portglenone, Ballymena BT44 8LJ, Northern Ireland, UK plant biomass; however, the increased leaching of $\mathrm{Hg}$ after thiosulphate treatment was observed.

Conclusions Lepidium sativum L. showed the potential of a non-hyperaccumulating plant that can be used during phytoextraction of Hg-contaminated soils in controlled conditions. Thiosulphate promoted the phytoextraction process by increasing the total $\mathrm{Hg}$ accumulation by whole plant and translocation of $\mathrm{Hg}$ to shoots of L. sativum $\mathrm{L}$. Thiosulphatemobilized $\mathrm{Hg}$ in soil, which increased the $\mathrm{Hg}$ leaching. This constitutes the limitation of applying the technique in the field due to risk of $\mathrm{Hg}$ transferring to deeper layers of soil or water. Applying the technique in the field should be preceded by further investigations.

Keywords Leaching · Lepidium sativum L · Mercury · Phytoextraction - Thiosulphate

\section{Introduction}

Soil contamination by mercury has become a serious problem in the world. Due to mercury toxicity and its physical and chemical properties, it constitutes a threat to the health of humans and wildlife, even in places which are not obviously contaminated. The risk is determined by both the likelihood of exposure and its chemical form.

The increasing concentration of mercury in the environment is mostly ascribed to human activity, which includes a variety of industrial processes, for example, coal burning, disposal of $\mathrm{Hg}$-containing products, mining, smelting and solid waste combustion.

Mercury is often deposited in soils, where concentrations of this element can be large. In soil, mercury can be absorbed onto the solid-phase of organic matter or minerals (Evans 1989). However, a substantial fraction of $\mathrm{Hg}$ undergoes several transformations, including leaching, 
volatilisation, methylation or biological reduction (Moreno et al. 2005a). These processes increase the $\mathrm{Hg}$ mobility thus causing the spreading of the pollution. Soils contaminated by mercury constitute a danger for all living organisms because of the possibility of mercury absorption by microbes and plants, whilst at the same time, transferring $\mathrm{Hg}$ to the food chain (Kabata-Pendias and Pendias 1999). Therefore, the techniques of soil reclamation are still being searched.

In methods of soil remediation adequate for Hg-polluted soils, physical and chemical treatments should be mentioned. Nevertheless, these techniques are relatively expensive and generate wastes that should be utilised.

An alternative method, which is viewed as environmentally friendly is phytoremediation. Phytoremediation refers to the use of higher plants to decrease the toxicity of pollutants. One phytoremediation category is phytoextraction. This consists of the uptake of contaminants from soil or water by plant roots, their translocation and accumulation in plant shoots. The pollutants can then be removed by harvesting the aboveground tissues (Rafati et al. 2011; Ali et al. 2013; Wang et al. 2012).

The main problem that occurs during phytoextraction is a low solubility of mercury in soil solution, which results in decreasing bioavailability of the metal. This problem can be solved by addition of chemical compounds straight to the soil. These chemicals promote the solubility of metals by the formation of watersoluble complexes and as a result, increase the metal bioavailability (Wang et al. 2011).

The researchers have demonstrated that mercury can form water-soluble complexes with several compounds like potassium iodide KI (Wang and Greger 2006) and ammonium thiocyanate $\mathrm{NH}_{4} \mathrm{SCN}$ (Moreno et al. 2005a). Moreover, investigations have also been conducted on the potential use of sodium thiosulphate $\mathrm{Na}_{2} \mathrm{~S}_{2} \mathrm{O}_{3}$ and ammonium thiosulphate $\left(\mathrm{NH}_{4}\right)_{2} \mathrm{~S}_{2} \mathrm{O}_{3}$ during induced phytoextraction of mercury-contaminated soils (Moreno et al. 2005a, b). The results of these studies showed that all of the aforementioned compounds increased the efficiency of phytoextraction compared to processes conducted without chemical enhancements. In citied studies, the potential of Phaseolus vulgaris L., Brassica juncea L., Vicia villosa L. and Chenopodium gluacum L. for $\mathrm{Hg}$ phytoextraction was evaluated. Nevertheless, there is still a lack of information about the leaching of mercury during the chemically induced phytoextraction.

This study presents (i) the possibility of using Lepidium sativum L. plants as $\mathrm{Hg}$-extractors (ii) the influence of sodium thiosulphate $\left(\mathrm{Na}_{2} \mathrm{~S}_{2} \mathrm{O}_{3}\right)$ on the mercury accumulation by $L$. sativum $\mathrm{L}$. and (iii) leaching of $\mathrm{Hg}$ in neutral $\mathrm{pH}$ after phytoextraction assisted by sodium thiosulphate $\left(\mathrm{Na}_{2} \mathrm{~S}_{2} \mathrm{O}_{3}\right)$.

\section{Materials and methods}

\subsection{Soil}

The soil used in the experiment was collected from Lodz (Poland) at a depth of 0-30 cm. After being air-dried, the soil was passed through a 2-mm nylon mesh. Soil density was measured using a cylinder with a volume of $100 \mathrm{~cm}^{3}$. The soil moisture was determined after drying at $105^{\circ} \mathrm{C}$ for $48 \mathrm{~h}$. Soil density was calculated as the ratio of soil dried weight to cylinder volume. The following soil properties were characterised as follows: $\mathrm{pH}$ was determined according to ISO 10 390:2005, organic matter according to ISO 14235:2003, total nitrogen according to ISO 11261:2002 and available phosphorous according to PN-P-04023:1996. Concentrations of chosen heavy metals in the soil $(\mathrm{Pb}, \mathrm{Cu}, \mathrm{Zn})$ were determined by AAS graphite furnace after acid microwave digestion. Concentration of $\mathrm{Hg}$ in soil was determined by cold vapour atomic absorption spectrometry (CV-AAS) after acid microwave digestion. In all determinations, atomic absorption standards, J.T. Baker, were used.

\subsection{Plant}

Lepidium sativum L. plants were used as $\mathrm{Hg}$ accumulators. These plants are characterised by a low vegetation period and low nutrient requirements. The seeds used in the experiments came from Grono Company (Wroclaw, Poland). The optimal scale of sowing was $10 \mathrm{~g}$ seeds $\mathrm{kg}^{-1}$ of fresh soil. The cultivation was provided in day/night system at temperature $22 / 19 \pm 1{ }^{\circ} \mathrm{C}$, respectively, and a 14 -h photoperiod. Cultivation pots were sprinkled with deionised water to keep the soil humidity at $35 \%$. The plant samples were collected 7 days after planting and were prepared for $\mathrm{Hg}$ determination. The samples were washed with deionised water to remove soil particles and weighed. Then, they were separated into roots and aboveground parts, dried at $35^{\circ} \mathrm{C}$ for $60 \mathrm{~h}$ and weighed once again. Plant samples were ground into powder and mineralized with $3 \mathrm{~mL}$ of $65 \% \mathrm{HNO}_{3}$ (Suprapur, Merck) in a Teflon bomb at $160{ }^{\circ} \mathrm{C}$ for $1 \mathrm{~h}$ (Cavallini et al. 1999). Concentration of mercury was determined by CV-AAS. Each of the cultures was cultivated in triplicate.

\subsection{Phytoextraction}

The phytoextraction process was conducted in soil artificially contaminated by mercury. The soil samples were put into plastic pots and supplemented by mercury (II) acetate $\left(\mathrm{CH}_{3} \mathrm{COO}\right)_{2} \mathrm{Hg}$ (Merck Company) in concentrations of 10 and $100 \mathrm{mg} \mathrm{kg}^{-1}$ soil dry weight. After $72 \mathrm{~h}$ of stabilization, sodium thiosulphate $\mathrm{Na}_{2} \mathrm{~S}_{2} \mathrm{O}_{3}$ (Merck Company) in concentrations of 100 or $500 \mathrm{mg} \mathrm{kg}^{-1}$ soil dry weight was added to pots supplemented earlier with mercury. The supplemented 
soil samples were stabilized for another $72 \mathrm{~h}$ before the plant cultivation started. The controls were supplemented with mercury but did not contain sodium thiosulphate. The blank samples were cultivated in unpolluted soil, supplemented by thiosulphate to check its influence on plant biomass (Fig. 1). Each of the soil samples was homogenised. After the plant cultivation, $\mathrm{Hg}$ concentration in plant tissues was determined using the method described above (Section 2.2).

\subsection{Leaching tests}

The leaching tests were conducted after the plant cultivation at pots presented at Fig. 1 at $\mathrm{pH}=7$ (distilled water). Fifteen grams of each soil sample was put in a round-bottomed flask and $150 \mathrm{~mL}$ of distilled water $(\mathrm{pH}=7)$ was added afterwards. The flasks were shaken for $1 \mathrm{~h}$ at $20^{\circ} \mathrm{C}$. After shaking, the soil samples were left for $24 \mathrm{~h}$ at room temperature and then filtered. The water extracts were acidified by concentrated nitric (V) acid $\left(\mathrm{HNO}_{3}\right)$ (Merck Company) and the concentration of $\mathrm{Hg}$ was determined after acid mineralization using $\mathrm{CV}$ AAS method (Smolinska and Krol 2012). Each of the variants of analysis was carried out in triplicate, at regular time periods of $1,5,10,15$ and 20 days.

\subsection{Calculation and statistical treatment}

Accumulation factor (AF) was calculated according to Wilson and Pyatt (2007), bioconcentration factor (BCF) was calculated according to Zhuang et al. (2007) and translocation factor (TF) was calculated following Zacchini et al. (2009).

All analyses in this experiment were performed independently for each of the plant material and were repeated three times. The data obtained (in three replications) was statistically analysed using ANOVA test in Excel Data Analysis. Analysis of variance was performed to determine the significance of differences between the pairs of means. The differences were statistically significant when $p$ value was less than 0.05 . A multiple range test was performed to find out which means are significantly different from others. This test is based on Fisher's least significant difference (LSD) procedure.

\section{Results}

\subsection{Physico-chemical properties of soil}

The soil subjected to investigations was representative of an urban soil collected in the city of Lodz, Poland. The soil could be classified as a sandy loam with a soil density of $1.2 \pm$ $0.1 \mathrm{~g} \mathrm{~cm}^{-3} \cdot \mathrm{pH}$ value was $6.45 \pm 0.01$. This result enabled to include the soil as slightly acidic according to the Soil Survey Division Staff (1993). The concentration of organic carbon, total nitrogen and available phosphorous $\left(\mathrm{g} \mathrm{kg}^{-1}\right.$ soil dry weight) was $5.47 \pm 0.83,0.52 \pm 0.10$ and $0.38 \pm 0.07$, respectively. Concentrations of these macronutrients were rather low, but sufficient for plant cultivation. The soil concentration of $\mathrm{Pb}, \mathrm{Cu}$ and $\mathrm{Zn}$ (mg kg $\mathrm{mg}^{-1}$ soil dry weight) was as follows: $0.047 \pm 0.005 ; 0.023 \pm 0.003$ and $0.039 \pm 0.008$, respectively. Due to very low concentrations of $\mathrm{Pb}, \mathrm{Cu}$ and $\mathrm{Zn}$ that made the natural soil background, the assumption was made that they have no influence on the experiment. The amount of the mercury in the soil was below the level of detection $\left(<0.005 \mu \mathrm{g} \mathrm{kg}^{-1}\right)$. With regards to the above, the soil was classified as uncontaminated.

\subsection{Phytoextraction}

Lepidium sativum L. plants were able to accumulate $\mathrm{Hg}$. However, plants cultivated in polluted soil accumulated $\mathrm{Hg}$ mainly in their belowground parts (Fig. 2, controls). Less than $8 \%$ of $\mathrm{Hg}$ was translocated to the shoots of L. sativum L. Thiosulphate treatment enhanced the total accumulation of $\mathrm{Hg}$ by L. sativum L. (Fig. 2). Hg concentration in thiosulphateassisted process was increased by $238-272 \%$ in whole plants of L. sativum L., in relation to controls. Concentrations of $\mathrm{Hg}$ in the roots of L. sativum L. maintained the same level regardless of both $\mathrm{Hg}$ and thiosulphate concentration in soil. It means that the accumulation of $\mathrm{Hg}$ increased mostly in aboveground parts of the plants. As can be seen in Fig. 2, Hg concentration in aerial parts of $L$. sativum L. increased after thiosulphate treatment. For $100 \mathrm{mg} \mathrm{kg}^{-1}$ of $\mathrm{S}_{2} \mathrm{O}_{3}{ }^{2-}$ treatment,

Fig. 1 Experimental scheme

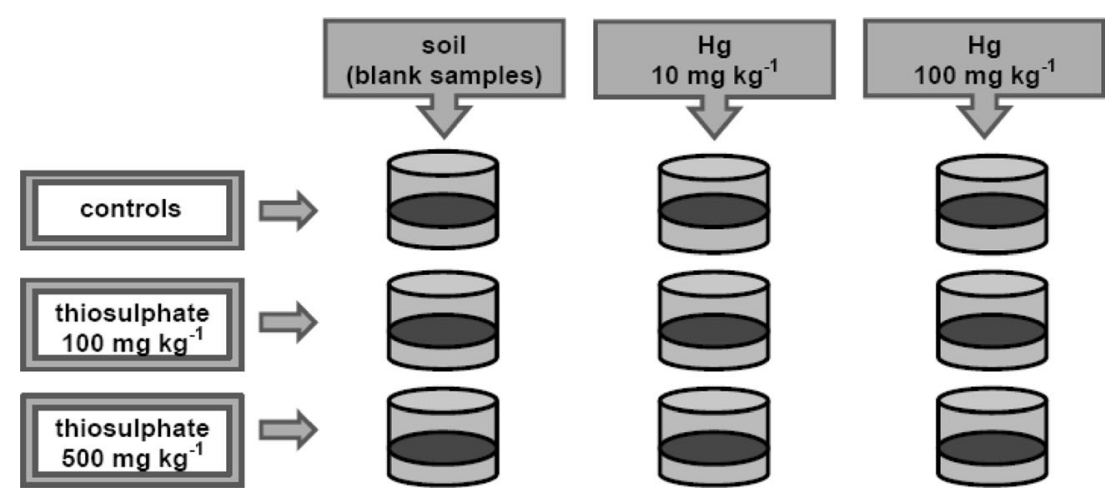


Fig. 2 Accumulation of $\mathrm{Hg}$ by Lepidium sativum $\mathrm{L}$. for soil polluted by mercury: $\mathbf{a}$ in concentration $10 \mathrm{mg} \mathrm{kg}^{-1}$ and $\mathbf{b}$ in concentration $100 \mathrm{mg} \mathrm{kg}^{-1}$.

Different letters above the bars indicate a significant difference at $p<0.05$
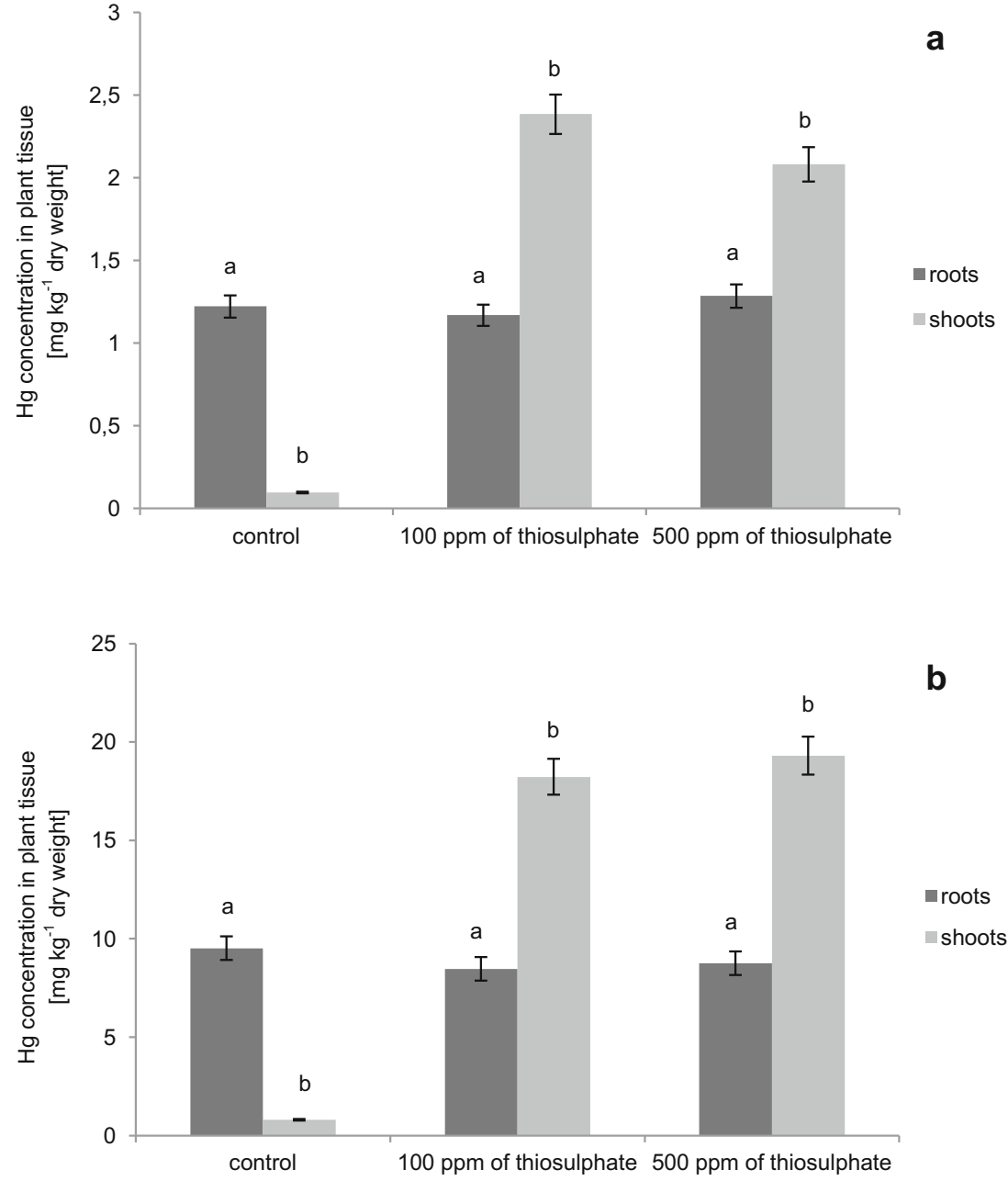

concentration of $\mathrm{Hg}$ in leaves and stems increased more than $2400 \%$.

One of the factors that determine the possibility of plant use in the field is its biomass. According to Table 1, biomass of Lepidium sativum L. was affected by $\mathrm{Hg}$. The comparison analysis indicated that higher $\mathrm{Hg}$ concentration in soil contributed to a decrease of plant biomass of about $35 \%$ in relation to the control. No statistically different values were found in the values of roots biomass for both $\mathrm{Hg}$ concentrations in soil. However, the content of fresh mass in aerial parts decreased with increasing concentrations of $\mathrm{Hg}$ in soil. Thiosulphate treatment had no influence on plant biomass.
Table 1 Effect of treatments on plant of Lepidium sativum L. grown in different $\mathrm{Hg}$ concentrations

Significant differences among thiosulphate treatments are indicated by a and $\mathrm{b}$ letters (mean \pm $\mathrm{SD}, n=3$; Fisher test $p<0.05$ )

\begin{tabular}{llll}
\hline $\begin{array}{l}\mathrm{Hg} \text { concentration } \\
{\left[\mathrm{mg} \mathrm{kg}^{-1} \text { dry weight }\right]}\end{array}$ & $\begin{array}{l}\text { Concentration of } \mathrm{Na}_{2} \mathrm{~S}_{2} \mathrm{O}_{3} \\
{\left[\mathrm{mg} \mathrm{kg}^{-1} \text { dry weight }\right]}\end{array}$ & $\begin{array}{l}\text { Fresh weight } \\
{[\mathrm{g}]}\end{array}$ & Roots \\
\cline { 2 - 3 } & & Aerial parts & $11.400 \pm 0.474 \mathrm{a}$ \\
0 & 0 & $18.659 \pm 0.874 \mathrm{a}$ & $11.703 \pm 0.745 \mathrm{~b}$ \\
0 & 100 & $18.062 \pm 1.125 \mathrm{a}$ & $10.210 \pm 0.496 \mathrm{a}$ \\
0 & 500 & $19.001 \pm 1.110 \mathrm{~b}$ & $6.508 \pm 0.699 \mathrm{a}$ \\
10 & 0 & $16.635 \pm 0.758 \mathrm{a}$ & $7.028 \pm 0.459 \mathrm{~b}$ \\
10 & 100 & $17.097 \pm 0.747 \mathrm{~b}$ & $6.895 \pm 0.688 \mathrm{~b}$ \\
10 & 500 & $17.898 \pm 0.658 \mathrm{~b}$ & $4.046 \pm 0.469 \mathrm{a}$ \\
100 & 0 & $15.239 \pm 1.047 \mathrm{a}$ & $5.127 \pm 0.698 \mathrm{~b}$ \\
100 & 100 & $17.052 \pm 1.701 \mathrm{~b}$ & $4.936 \pm 0.558 \mathrm{~b}$ \\
100 & 500 & $16.040 \pm 0.745 \mathrm{~b}$ & \\
\hline
\end{tabular}


Plant growth was healthy and no visual differences appeared. After statistical analysis, the significant differences between biomass of plants cultivated on $\mathrm{Hg}$-polluted soil and thiosulphate breeding were observed.

The values of bioconcentration factor (BCF), accumulation factor $(\mathrm{AF})$ and translocation factor $(\mathrm{TF})$ for phytoextraction promoted by thiosulphate are included in Table 2 . Thiosulphate treatment significantly affects all of the described factors regardless of $\mathrm{Hg}$ concentration in soil. Accumulation factor increased over 2.5 times in all variants of investigations compared to controls. The results of the investigation showed that BCF for L. sativum L. was 0.1820.238 for different treatments. Although the investigated plant cannot be classified as a hyperaccumulator, it has a potential for $\mathrm{Hg}$ accumulation due to translocation of $\mathrm{Hg}$ to the aerial parts. Calculation of TF gave very promising results. Thiosulphate treatment improved the translocation of $\mathrm{Hg}$ to aboveground parts of plants 10 times more compared to control.

\subsection{Leaching of $\mathrm{Hg}$}

Determination of $\mathrm{Hg}$ leaching during thiosulphate treatment was provided by the evaluation of $\mathrm{Hg}$ extracted from soil after plant cultivation. The results are shown in Fig. 3. Leaching of $\mathrm{Hg}$ at neutral $\mathrm{pH}$ was dependant on both $\mathrm{Hg}$ concentration in soil and the time of analysis. For soil contaminated with $10 \mathrm{mg} \mathrm{kg}^{-1}$ dry weight of $\mathrm{Hg}$, the lowest amount of $\mathrm{Hg}$ in water leachates was observed for control samples. The $\mathrm{Hg}$ concentration ranged from $2.55 \mathrm{mg} \mathrm{kg}^{-1}$ on the first day of investigation to $2.83 \mathrm{mg} \mathrm{kg}^{-1}$ on the 20th day. Application of thiosulphate increased the $\mathrm{Hg}$ concentration in water extracts by $87-90 \%$ for $100 \mathrm{mg} \mathrm{kg}^{-1}$ of $\mathrm{S}_{2} \mathrm{O}_{3}{ }^{2-}$ to $109-115 \%$ for thiosulphate treatment at a concentration of $500 \mathrm{mg} \mathrm{kg}^{-1} \mathrm{com}-$ pared to control. Moreover, the significant increase of $\mathrm{Hg}$ amount during the time of analysis was observed for the

Table 2 Comparison of effective accumulation by whole plant $\left(\mathrm{E}_{\mathrm{WP}}\right)$, shoots $\left(E_{S}\right)$ and translocation $(T)$ in different variants of the process

\begin{tabular}{|c|c|c|c|c|c|c|}
\hline \multirow[t]{3}{*}{ Factor } & \multirow{2}{*}{\multicolumn{3}{|c|}{$\begin{array}{l}\mathrm{Hg} \text { concentration } \\
10 \\
{\left[\mathrm{mg} \mathrm{kg}^{-1} \text { soil dry weight }\right]} \\
\text { Concentration of } \mathrm{Na}_{2} \mathrm{~S}_{2} \mathrm{O}_{3} \\
{\left[\mathrm{mg} \mathrm{kg}^{-1} \text { soil dry weight }\right]}\end{array}$}} & \multirow{2}{*}{\multicolumn{3}{|c|}{$\begin{array}{l}\text { Hg concentration } \\
100 \\
{\left[\mathrm{mg} \mathrm{kg}^{-1} \text { soil dry weight }\right]} \\
\text { Concentration of } \mathrm{Na}_{2} \mathrm{~S}_{2} \mathrm{O}_{3} \\
{\left[\mathrm{mg} \mathrm{kg}^{-1} \text { soil dry weight }\right]}\end{array}$}} \\
\hline & & & & & & \\
\hline & 0 & 100 & 500 & 0 & 100 & 500 \\
\hline $\mathrm{AF}$ & 0.141 & 0.355 & 0.337 & 0.103 & 0.267 & 0.281 \\
\hline $\mathrm{BCF}$ & 0.010 & 0.238 & 0.208 & 0.008 & 0.182 & 0.193 \\
\hline $\mathrm{TF}$ & 0.068 & 0.671 & 0.618 & 0.077 & 0.683 & 0.688 \\
\hline
\end{tabular}

Accumulation factor $(\mathrm{AF})=\left[\mathrm{Hg}_{\text {whole plant }} / \mathrm{Hg}_{\text {soil }}\right]$; bioconcentration factor $(\mathrm{BCF})=\left[\mathrm{Hg}_{\text {shoots }} / \mathrm{Hg}_{\text {soil }}\right]$; translocation factor $(\mathrm{TF})=\left[\mathrm{Hg}_{\text {shoots }} / \mathrm{Hg}_{\text {roots }}\right]$
$100 \mathrm{mg} \mathrm{kg}^{-1}$ dry weight of $\mathrm{S}_{2} \mathrm{O}_{3}{ }^{2-}$ treatment. For the higher thiosulphate concentration in soil, $\mathrm{Hg}$ concentration in water extracts stayed almost on the same level.

Slightly different results were observed for the process carried out in soil contaminated with $100 \mathrm{mg} \mathrm{kg}^{-1}$ dry weight of $\mathrm{Hg}$. In this part of the study, the increase of $\mathrm{Hg}$ concentration was noticed regardless of the thiosulphate concentration during the time of conducted experiment. For $500 \mathrm{mg} \mathrm{kg}^{-1}$ of $\mathrm{S}_{2} \mathrm{O}_{3}{ }^{2-}$ treatment, $\mathrm{Hg}$ concentration in extracts increased by $29 \%$ on the 1 st day to $44 \%$ on the 20 th day, respectively, relative to control. After phytoextraction of $\mathrm{Hg}$ by L. sativum L. assisted by thiosulphate about $40-53 \%$ of $\mathrm{Hg}$ stayed mobile in soils.

\section{Discussion}

Plant used in the investigations accumulated $\mathrm{Hg}$ mainly in roots. This result is a confirmation of investigations conducted by Perez-Sanz et al. (2012) for Silene vulgaris L. and Shiyab et al. (2009) for Brassica juncea L., who stated that increasing concentration of $\mathrm{Hg}$ in soil negatively affected plant accumulation. Slight transfer of $\mathrm{Hg}$ to aboveground parts of plants can be a result of plant response to stress conditions caused by mercury presence in soil. The typical answer is either formation of phytochelatines in plant roots or binding the pollutants to the cell wall of root and as a consequence, deposition of the pollutant in that part of plant (Suszczynski and Shann 1995; Greger et al. 2005).

Application of thiosulphate promoted Hg phytoextraction. The results obtained for L. sativum L. are not as spectacular as those obtained in previous studies by Moreno et al. (2004) and Wang et al. (2011). These authors reported that the Hg concentration in the whole plants of Brassica juncea $\mathrm{L}$. and Chenopodium glaucum L. exceeded 1800-4500 \%, respectively, compared to controls. This phenomenon may be explained through the decreasing toxicity of $\mathrm{Hg}$ which was chelated with thiosulphate. Moreover, according to Wang et al. (2011) thiosulphate demonstrated properties of a good ligand for $\mathrm{Hg}$ in soil by forming water-soluble complexes, like $\mathrm{Hg}-\mathrm{S}_{2} \mathrm{O}_{3}$. Formation of chelates with $\mathrm{Hg}$ increased its solubility thus increasing $\mathrm{Hg}$ uptake. Plant roots may be able to select $\mathrm{Hg}-\mathrm{S}_{2} \mathrm{O}_{3}$ complex and transport it to shoots in preference to other mercury complexes in soil (Moreno et al. 2005b). The typical pathway of transporting metals uptaken by plants is the symplastic one. Nowack et al. (2006) reported that addition of chelates to the soil can change the primary route to apoplastic and in a consequence, increase the translocation of metals to aboveground parts of plants.

$\mathrm{Hg}$ is a highly toxic element that can negatively affect plant biomass. In previous studies, Patra and Sharma (2000) stated that dry matter production by higher plants such as Brassica 
Fig. 3 Concentration of $\mathrm{Hg}$ extracted from soil after phytoextraction process for: a soil contamination by $10 \mathrm{mg} \mathrm{kg}^{-1}$ of $\mathrm{Hg}$ and $\mathbf{b}$ soil contamination by $100 \mathrm{mg} \mathrm{kg}^{-1}$ of $\mathrm{Hg}$
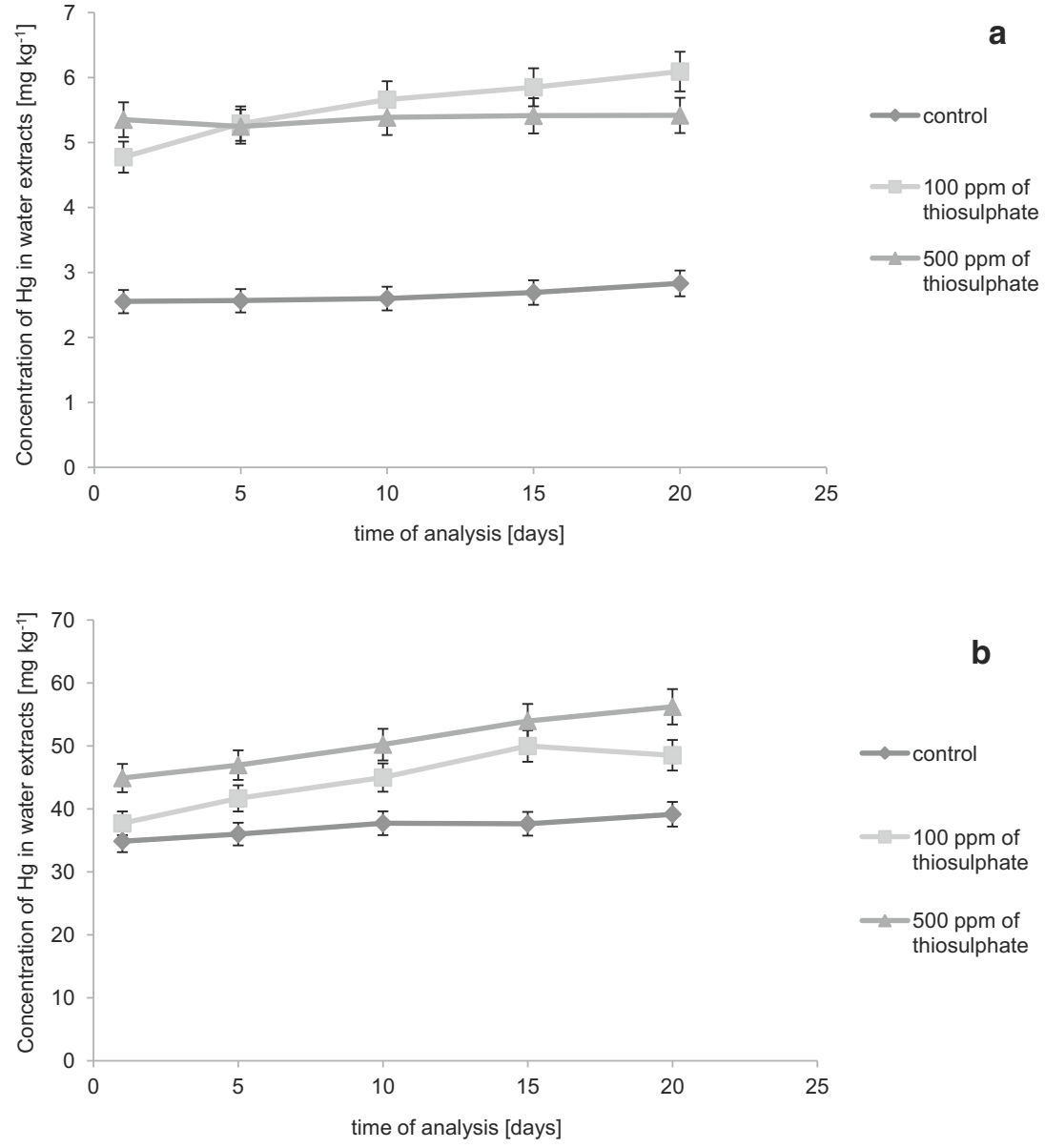

oleracea L. var. capitata, Chinese cabbage, Beta vulgaris L. or Pisum sativum L. is inversely proportional to the concentration of $\mathrm{Hg}$ in soil. The similar tendency was observed for L. sativum L. The plant biomass production is one of the major key factors that determine the efficiency of phytoextraction. The other factors that describe the effectiveness of this process are accumulation, bioconcentration and translocation factors (McGrath and Zhao 2003). The accumulation factor (AF) identifies the ratio of metal accumulation by whole plant to its concentration in soil, whilst bioconcentration factor (BCF) is defined as the ratio of metal concentration in plant shoots to metal concentration in soil. The third component that can be useful during evaluation of phytoextraction efficiency is translocation factor (TF). The experiment showed that thiosulphate treatment increased all of the above-mentioned factors. According to Sakakibara et al. (2011), the bioconcentration factor is very important when considering the potential of a given plant species for phytoextraction. The ideal BCF of plants having the potential for phytoextraction is greater than 1 (for hyperaccumulator plants). However, the high concentrations of metals in soil can lead to decreasing BCF values (Ali et al. 2013; van der Ent et al. 2013).

Application of chelates to the soil during assisted phytoextraction can lead to increased solubility of metals thus increasing their bioavailability. Nevertheless, the increasing solubility can result in transferring the pollutants through lower levels of pedosphere to groundwater, contributing to spreading the contamination. Therefore, the leaching tests under laboratory conditions should be provided before fieldusing method. There are many factors that can influence the leaching of $\mathrm{Hg}$ in natural soil environments. Leaching of $\mathrm{Hg}$ is dependent on the physical and chemical properties of soil (soil water, sorption, redox conditions, mechanical and chemical properties of soil), as well as the concentration of pollution and atmospheric precipitations (Chaney et al. 1997). Under these conditions, soluble forms of mercury can transform to insoluble and inversely, which changes leaching characteristics. The presented results showed that thiosulphate had a potential to mobilize the $\mathrm{Hg}$ in soil. The high concentration of $\mathrm{Hg}$ in water extracts suggested that after thiosulphate treatment, $\mathrm{Hg}$ can be transferred to below the root zone of plants and cause a danger to other ecosystems.

The results presented in this study are very promising, especially those that indicate the increasing $\mathrm{Hg}$ accumulation by $L$. sativum L. after thiosulphate amendment. Very high translocation rates create the possibility of trying to use the technique in the field conditions. Nevertheless, there are some limitations that have to be taken into consideration before the 
field testing. The presented process was conducted in a laboratory under controlled conditions. Low soil humidity was kept to maintain the moisture just below field water capacity and at the same time, to ensure no leaching during plant cultivation and thus no vertical movement of $\mathrm{Hg}$ to below the root zone area of plants. In real conditions, the field water capacity should be analysed before the field testing technique. Therefore, in any field application of the presented technique, both the water use efficiency of the plants as well as field water capacity would need to be considered, mitigating any potential environmental risk.

Moreover, the leaching experiment showed that the application of thiosulphate-mobilized $\mathrm{Hg}$, which means that $\mathrm{Hg}$ changed its form in the soil solution. Further investigations should be provided to verify the $\mathrm{Hg}$ form(s) after thiosulphate treatment. In general, the soluble exchangeable and specifically sorbed fractions of soil metal have higher bioavailability than other fractions (Wang et al. 2012). Therefore, Hg in these forms can be transported easier to deeper layers of soil or water spreading the pollution. Information about $\mathrm{Hg}$ forms after thiosulphate treatment would be a key factor that enables to verify the $\mathrm{Hg}$ behaviour in soil solution.

Van Nevel et al. (2007) reported that the use of some chelators could increase the risk of contaminant leaching, limiting at the same time, the use of suggested technique in the field. Based on the provided leaching experiments, thiosulphate can be included to these chelates. After thiosulphate treatment, almost half of the total $\mathrm{Hg}$ concentration stayed mobile in soil, which means that the risk of $\mathrm{Hg}$ leaching is highly probable. However, we believe that this risk may be mitigated through continuous planting of short vegetation period plant, like L. sativum L., to extract $\mathrm{Hg}$ from soil. The possibility of risk reduction also exists in lowering the dose of thiosulphate during assisted phytoextraction. However, some further investigations should be conducted to verify these proposals.

\section{Conclusions}

Lepidium sativum L. showed the potential of a nonhyperaccumulating plant that can be used during the phytoextraction of Hg-contaminated soils. This plant accumulated about $10-14 \%$ of $\mathrm{Hg}$ depending on its concentration in soil. Thiosulphate promoted the phytoextraction process by increasing the total $\mathrm{Hg}$ accumulations by plant. Moreover, after thiosulphate treatment, $\mathrm{Hg}$ translocation to aerial parts of $L$. sativum L. increased greater than 10 times in relation to the unassisted process. No negative effect of thiosulphate on plant biomass was observed.

Although mercury uptake by L. sativum L. was promoted after thiosulphate treatment, the potential risk for the environment should be considered. The presented results showed that thiosulphate-mobilized $\mathrm{Hg}$ in soil, which increased the $\mathrm{Hg}$ leaching. This constitutes the limitation of applying the technique in the field due to the risk of $\mathrm{Hg}$ transferring to deeper layers of soil or water. However, continuous phytoextraction and/or lowering dosage of thiosulphate may mitigate that problem.

Open Access This article is distributed under the terms of the Creative Commons Attribution License which permits any use, distribution, and reproduction in any medium, provided the original author(s) and the source are credited.

\section{References}

Ali H, Khan E, Sajad MA (2013) Phytoremediation of heavy metalsconcept and applications. Chemosphere 91:869-881

Cavallini A, Natali L, Durante M, Maserti B (1999) Mercury uptake, distribution and DNA affinity in durum wheat (Triticum durum Desf.) plants. Sci Total Environ 243(244):119-127

Chaney RR, Malik M, Li YM, Brewer EP, Angle JS, Baker A (1997) Phytoremediation of soil metals. Curr Opin Biotech 8:279-284

Evan LJ (1989) Chemistry of metal retension by soils. Environ Sci Technol 23:1046-1056

Greger M, Wang Y, Neuschutz C (2005) Absence of Hg transpiration by shoot after $\mathrm{Hg}$ uptake by roots of six terrestrial plant species. Environ Poll 134:201-208

Kabata-Pendias A, Pendias H (1999) Biogeochemistry of trace metals. PWN Warsaw, Poland, pp 170-183

McGrath SP, Zhao FJ (2003) Phytoextraction of metals and metalloids from contaminated soil. Curr Opin Biotechnol 14:277-282

Moreno FN, Anderson CWN, Steward RB, Robinson BH (2004) Phytoremediation of mercury contaminated mine tailings by induced plant-mercury accumulation. Environ Pract 6:165-175

Moreno FN, Anderson CWN, Steward RB, Robinson BH, Ghomshei M, Meeck JA (2005a) Induced plant uptake and transport of mercury in the presence of sulphur-containing ligands and humic acids. New Phytol 166:445-454

Moreno FN, Anderson CWN, Steward RB, Robinson BH, Nomura R, Ghomshei M, Meeck JA (2005b) Effect of thioligands on plant $\mathrm{Hg}$ accumulation and volatilisation from mercury contaminated mine tailings. Plant Soil 275:233-246

Nowack R, Schulin R, Robinson B (2006) Critical assessment of chelantenhanced metal phytoextraction. Environ Sci Technol 40: $5225-5232$

Patra M, Sharma A (2000) Mercury toxicity in plants. Bot Rev 66: 376-422

Perez-Sanz A, Millan R, Sierra MJ, Alarcon R, Garcia P, Gil-Diaz M, Vazquez S, Carmen Lobo M (2012) Mercury uptake by Silene vulgaris grown on contaminated spiked soils. J Environ Manag 95:5233-5237

Rafati M, Khorasami N, Moattar F, Shivany A, Moraghebi F, Hosseinzadeh S (2011) Phytoremediation potential of Populus alba and Mones alba from cadmium, chromium and nickel adsorption from polluted soil. Int J Environ Res 5:961-970

Sakakibara M, Ohmori Y, Ha NTH, Sano S, Sera K (2011) Phytoremediation of heavy metal contaminated water and sediment by Eleocharis acicularis. Clean - Soil, Air, Water 39:735-741 
Shiyab S, Chen J, Hau FX, Monts DL, Matta FB, Gu M, Su Y (2009) Phytotoxicity of mercury in Indian mustard (Brassica juncea L.). Ecotoxicol Environ Safe 72:619-625

Smolinska B, Krol K (2012) Leaching of mercury during phytoextraction assisted by EDTA, KI and citric acid. J Chem Technol Biot 87: $1360-1365$

Soil Survey Division Staff (1993) Soil survey manual. Soil Conservation Service, U.S. Department of Agriculture Handbook 18

Suszczynski EM, Shann JR (1995) Phytotoxicity and accumulation of mercury in tobacco subjected to different exposure routes. Environ Toxicol Chem 14:61-67

van der Ent A, Bake AJM, Reeves RD, Pollard AJ, Schat H (2013) Hyperaccumulators of metal and metalloids trace elements: facts and fiction. Plant Soil 362:319-334

Van Nevel L, Mertens J, Oorts K, Verheyen K (2007) Phytoextraction of metals from soils: how far from practice? Environ Poll 150: $34-40$
Wang V, Greger M (2006) Use of iodide to enhance the phytoextraction of mercury contaminated soil. Sci Total Environ 368:30-39

Wang X, Feng XB, Anderson CWN, Qui GL, Ping L, Bao ZD (2011) Ammonium thiosulphate enhanced phytoextraction from mercury contaminated soil - results from greenhouse study. J Hazard Mater 186:119-127

Wang J, Feng X, Anderson CWN, Xing Y, Shang L (2012) Remediation of mercury contaminated sites - a review. J Hazard Mater 221-222:1-18

Wilson B, Pyatt FB (2007) Heavy metal bioaccumulation by the important food plant Olea europaea L. in an ancient metalliferous polluted area of Cyprus. Bull Environ Contam Toxicol 78:390-394

Zacchini M, Pietrini F, Mungozza GS, Iori V, Pietrosanti L, Massicci A (2009) Metal tolerance, accumulation and translocation in poplar and willow clones treated with cadmium in hydroponics. Water Air Soil Poll 197:23-34

Zhuang P, Yang Q, Wang H, Shu W (2007) Phytoextraction of heavy metals by eight plant species in the field. Water Air Soil Poll 184: 235-242 